\title{
Consequences of dam construction upstream of the Upper Paraná River floodplain (Brazil): a temporal analysis of the Chironomidae community over an eight-year period
}

\author{
Rosin, GC. ${ }^{\text {a* }}$, Oliveira-Mangarotti, DP. ${ }^{\mathrm{a}}$ Takeda, AM. ${ }^{\mathrm{b}}$ and Butakka, CMM. ${ }^{\mathrm{a}}$ \\ aPrograma de Pós-graduação em Ecologia de Ambientes Aquáticos Continentais, \\ Universidade Estadual de Maringá - UEM, \\ Av. Colombo, 5790, Maringá, CEP 87020-900, PR, Brazil \\ bPrograma de Pós-Graduação em Ecologia de Ambientes Aquáticos Continentais - PEA, \\ Departamento de Biologia, Núcleo de Pesquisas em Limnologia, Ictiologia e Aqüicultura - Nupélia \\ Universidade Estadual de Maringá - UEM, \\ Av. Colombo, 5790, Maringá, CEP 87020-900, PR, Brazil \\ *e-mail: gisakris@yahoo.com.br
}

Received November 11, 2008 - Accepted March 7, 2009 - Distributed June 30, 2009

(With 8 figures)

\begin{abstract}
Our study aimed to identify patterns of temporal variation and changes in the structure of the community of Chironomidae larvae in two rivers in the Upper Paraná River floodplain after the construction of a reservoir upstream (Porto Primavera). Samples were taken with a Petersen grab, and were obtained between 2000 and 2007. Chironomidae larvae were identified down to the lowest taxonomic level possible. The high richness of Chironomidae observed in the Paraná and Ivinhema Rivers (100 morphospecies) in comparison to the world average of rivers of the same size (44 species) emphasizes the importance of these habitats for the maintenance of biodiversity. The composition and density of Chironomidae in the years 2000 and 2001 differed from the other years. This period was characterized by extreme changes in the Paraná River flow caused by the closing of the Porto Primavera Dam, which added to a severe dry period in late 2001. The different compositions of morphospecies and the higher similarities in subsequent years are indicative of the recovery and adaptation of the community. In spite of the changes in the composition of morphospecies, diversity was maintained and the community continued to respond to fluctuations in the hydrometric level.
\end{abstract}

Keywords: temporal and spatial variation, Chironomidae, floodplain, damming.

\section{Conseqüências da construção de um reservatório a montante da planície aluvial do Alto Rio Paraná (Brasil): análises temporais da comunidade Chironomidae em um período de oito anos}

\begin{abstract}
Resumo
Este trabalho teve por objetivos identificar padrões de variação temporal e alterações ocorridas na estrutura da comunidade de larvas de Chironomidae de dois rios da planície aluvial do Alto Rio Paraná nos anos subseqüentes ao fechamento de um reservatório à montante, Porto Primavera. As amostras foram coletadas de 2000 a 2007 com um pegador do tipo Petersen, modificado. As larvas de Chironomidae foram identificadas até a menor categoria possível. A elevada riqueza de Chironomidae observada nos rios Paraná e Ivinhema (100 morfoespécies), quando comparada com a média mundial para rios de mesmo porte (44 espécies), ressalta a importância desses ambientes para a manutenção da biodiversidade. Tanto pela dominância, como também pela composição e densidade numérica, verificou-se que os anos de 2000 e 2001 diferiram dos demais. Este foi um período de fortes alterações no fluxo do Rio Paraná causado pela instalação do reservatório Porto Primavera aliado a uma grande seca ocorrida no final de 2001. Uma nova composição de morfoespécies e maior semelhança entre os anos seguintes são um indicativo da recuperação e adaptação da comunidade. Apesar das mudanças na composição de morfoespécies a diversidade foi mantida e a comunidade continua respondendo às flutuações do nível hidrométrico.
\end{abstract}

Palavras-chave: variações espaciais e temporais, Chironomidae, planície de inundação, represamento. 


\section{Introduction}

Research has demonstrated that the Upper Paraná River floodplain has been severely affected by anthropogenic effects such as the removal of riparian vegetation, biocide loads, discharge of domestic sewage and, most importantly, the construction of dams (Agostinho et al., 2008). Dams have altered the natural flood regime, and consequently the structure and dynamics of the floodplain (Agostinho et al., 2004).

Alterations in the flood regime can be the most serious and continuous risk to the ecological sustainability of a river and its floodplains (Naiman et al., 1995; Sparks, 1995; Lundqvist, 1998; Ward et al., 1995). Regulation of fluvial discharge causes significant changes in the magnitude, duration, periodicity and frequency of flood pulses and in the transport of sediments (Rocha, 2001; Hayakawa, 2007).

Over the past 35 years, the discharge system of the Paraná River has been altered by the operation of dams located upstream. As reservoirs were constructed, the Paraná River became a regulated river (Rocha et al., 1998; 2001; Rocha, 2002). Construction of the Porto Primavera Dam (1998) intensified this control (Silva, 2007). The first filling stage of the reservoir began in December 1998, and the second stage occurred only in March 2001. These filling activities changed the hydrological regime of the Upper Paraná River floodplain. Despite the sequence of reservoirs upstream, flood pulses are still the main factor controlling the structure and function of this ecosystem (Agostinho et al., 2008).

During the historical formation of their life cycles, aquatic species developed strategies that depend on the natural flow regime. Therefore, changes in this regime can reduce the diversity of native species (Bunn and Arthington, 2002). The Chironomidae community is not an exception, and in the Upper Paraná River floodplain temporal variations of this community are directly linked to the hydrosedimentological regime (Takeda et al., 1997; Higuti and Takeda, 2002; Higuti, 2004; Takeda et al., 2004; Rosin and Takeda, 2007).

Chironomidae larvae are of particular interest ecologically because they occur in a wide variety of habitats (Ferrington, 2008) as they are able to survive under several environmental conditions and are often abundant in freshwater (Pinder, 1995). For these reasons, Chironomidae have been included in almost all monitoring and impact assessment programs in aquatic environments (Specziár and Biró, 1998; Fesl, 2002; Piédras et al., 2006).

Based on the hypothesis that the community structure of Chironomidae has changed in terms of its composition, diversity, density and dominance since the construction of the Porto Primavera Dam, our study aimed to: 1) characterize the Chironomidae community with regard to density and taxonomic composition at the sampling sites; and 2) identify patterns of temporal varia- tion and changes in the structure of the community over time.

\section{Materials and Methods}

Our study is part of a larger project (Long-Term Ecological Research - LTER site 6) entitled: The Upper Paraná River Floodplain: Structure and Environmental Processes.

\subsection{Characterization of the study area}

The Paraná River is the main river of the La Plata Basin, formed by the rivers Grande and Paranaíba in the Central-South region of Brazil. The first third of its basin (the Upper Paraná River) is located in Brazil and is intensely dammed.

The Upper Paraná River floodplain was originally $480 \mathrm{~km}$ in length; however, after the construction of the Porto Primavera Dam (1998) its extent was reduced to $230 \mathrm{~km}$, between Porto Primavera and the Itaipu Reservoir (Agostinho et al., 2008). The Upper Paraná River floodplain also includes many secondary channels, ponds, the Baia River and stretches of the Ivaí and Ivinhema Rivers (Figure 1).

Our study was conducted in two of the main channels of this floodplain: one in Paraná River and one in Ivinhema River. The studied stretch of the Paraná River was located near the City of Porto Rico (Paraná State) on the sandstone of the Caiuá Formation (Souza-Filho and Stevaux, 2004), with a width of approximately $950 \mathrm{~m}$ and a mean flow of $0.30 \mathrm{~m} / \mathrm{s}$. The high transparency of the water in this stretch is due to the cascade of reservoirs upstream (Rocha and Thomaz, 2004).

The Ivinhema River flows parallel to the Paraná River in its lower stretches (Stevaux et al., 1997), where it has an average depth of $3.9 \mathrm{~m}$ and a mean flow of $0.20 \mathrm{~m} / \mathrm{s}$. This river has no dams, transports high loads of sediment and nutrients (Agostinho et al., 2004) and presents distinct vegetation on its margins, such as herbaceous vegetation, macrophyte banks and large areas with riparian forests at several different stages of regeneration.

Except for their conductivity values, limnological variables were only slightly different between the rivers. Regarding the hydric phases, values of dissolved oxygen were generally higher in low water periods (the limnophase) and lower in high water periods (the potamophase) (Table 1).

\subsection{Sampling and processing}

Zoobenthos were collected from 2000 to 2007, with three samplings conducted in 2001, two in 2003 and four between 2004 and 2007. Four samples were taken using a Petersen grab (areas of Petersen $=0.0187 \mathrm{~m}^{2}$ from 2000 to 2002, and $0.0345 \mathrm{~m}^{2}$ in the other years) at each sampling site: three for biological analyses and one for sedimentological analyses. Values of water temperature $\left({ }^{\circ} \mathrm{C}\right)$, dissolved oxygen concentration $\left(\mathrm{mg} . \mathrm{L}^{-1}\right), \mathrm{pH}$ and conductivity $\left(\mu \mathrm{S} . \mathrm{cm}^{-1}\right)$ were recorded at each sampling 


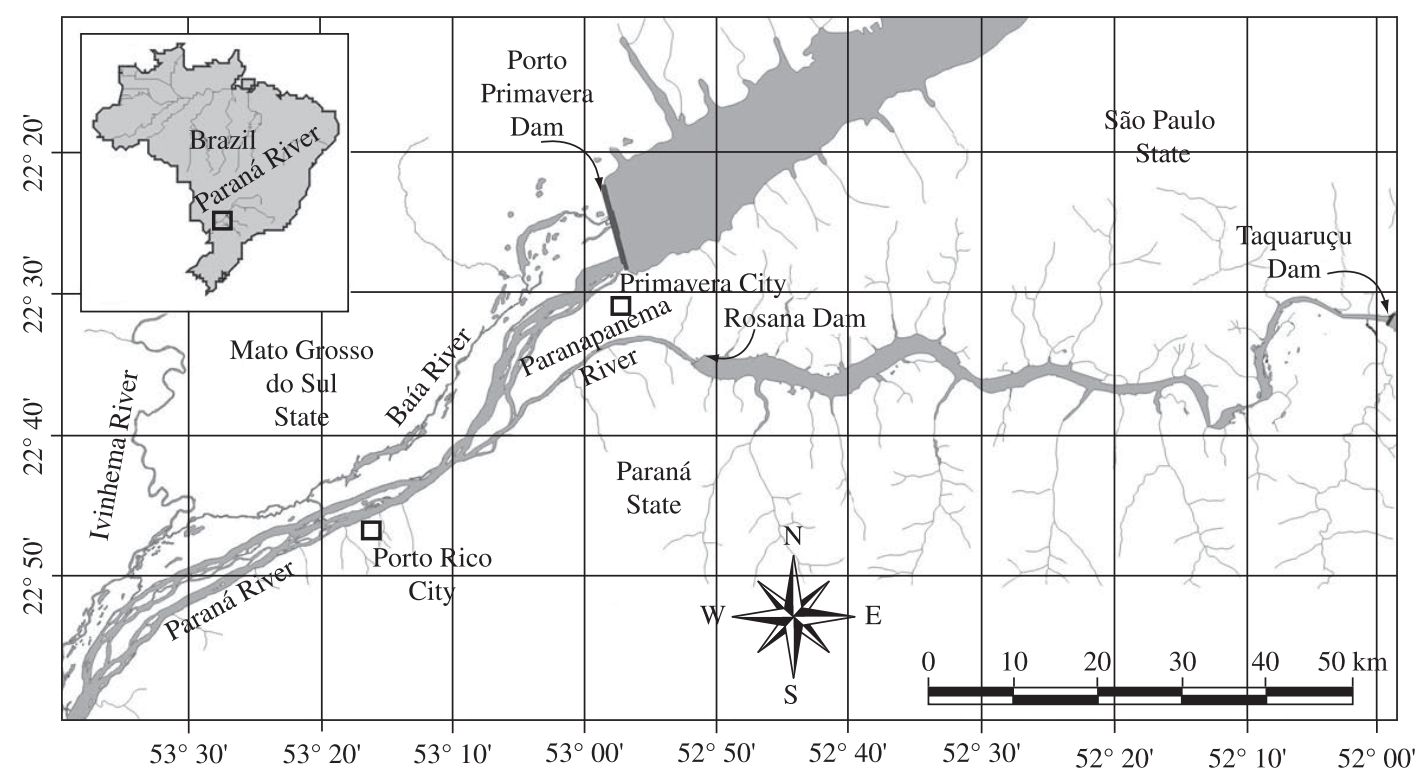

Figure 1. Location of the study area and sample points.

Table 1. Mean \pm SD (in parentheses) of the following limnological variables in the Paraná and Ivinhema Rivers between the years 2000 and 2007: water temperature, electric conductivity, $\mathrm{pH}$ and dissolved oxygen.

\begin{tabular}{|c|c|c|c|c|c|c|}
\hline River & Year & Period & $\begin{array}{c}\text { Water } \\
\text { temperature }\left({ }^{\circ} \mathbf{C}\right)\end{array}$ & $\begin{array}{c}\text { Conductivity } \\
\left(\mu{\left.\mathrm{S} . \mathrm{cm}^{-1}\right)}^{-1}\right.\end{array}$ & pH & $\begin{array}{c}\text { Dissolved oxygen } \\
\left(\mathrm{mg}^{\left.-L^{-1}\right)}\right.\end{array}$ \\
\hline \multirow[t]{16}{*}{ Paraná } & \multirow[t]{2}{*}{2000} & Potamophase & $25.95(1.48)$ & $57.2(5.98)$ & $7.16(0.09)$ & $8.95(0.77)$ \\
\hline & & Limnophase & $23.38(3.88)$ & 59.25 (3.92) & $7.29(0.25)$ & $8.13(1.25)$ \\
\hline & \multirow[t]{2}{*}{2001} & Potamophase & $23.58(9.61)$ & $41.70(17.6)$ & $6.80(0.15)$ & $8.00(0.87)$ \\
\hline & & Limnophase & $22.1(1.22)$ & $59.37(1.62)$ & $7.46(0.48)$ & $7.75(0.72)$ \\
\hline & \multirow[t]{2}{*}{2002} & Potamophase & $27.33(0.49)$ & $57.97(3.22)$ & $7.24(0.10)$ & $7.34(1.08)$ \\
\hline & & Limnophase & $22.55(4.35)$ & $53.57(2.30)$ & $7.18(0.18)$ & $8.87(0.19)$ \\
\hline & \multirow[t]{2}{*}{2003} & Potamophase & $29.33(0.12)$ & $51.4(0.01)$ & $7.00(0.02)$ & $8.19(0.02)$ \\
\hline & & Limnophase & $20.53(0.40)$ & $61.27(3.00)$ & $7.82(0.76)$ & $8.19(0.02)$ \\
\hline & \multirow[t]{2}{*}{2004} & Potamophase & $24.26(5.00)$ & $56.23(4.21)$ & $7.22(0.10)$ & $7.99(0.51)$ \\
\hline & & Limnophase & $25.02(1.49)$ & $59.07(4.22)$ & $6.81(0.19)$ & $9.12(0.89)$ \\
\hline & \multirow[t]{2}{*}{2005} & Potamophase & $25.80(2.27)$ & $59.00(4.01)$ & $7.35(0.13)$ & $7.52(0.88)$ \\
\hline & & Limnophase & $23.57(3.40)$ & $68.78(1.64)$ & $7.40(0.17)$ & $8.06(0.22)$ \\
\hline & \multirow[t]{2}{*}{2006} & Potamophase & $23.70(3.35)$ & $54.73(12.71)$ & $6.97(0.15)$ & $8.03(0.33)$ \\
\hline & & Limnophase & $24.93(3.10)$ & $58.43(8.06)$ & $7.82(0.33)$ & $8.09(0.67)$ \\
\hline & \multirow[t]{2}{*}{2007} & Potamophase & $25.18(4.40)$ & $55.77(6.48)$ & $7.54(0.23)$ & $8.42(0.91)$ \\
\hline & & Limnophase & $25.95(1.62)$ & $59.97(4.05)$ & $7.85(0.61)$ & $8.21(0.73)$ \\
\hline \multirow[t]{16}{*}{ Ivinhema } & \multirow[t]{2}{*}{2000} & Potamophase & $25.46(1.43)$ & $41.33(2.34)$ & $6.90(0.24)$ & $7.45(0.98)$ \\
\hline & & Limnophase & $22.18(4.51)$ & 42.35 (1.36) & $6.82(0.22)$ & $7.22(0.87)$ \\
\hline & \multirow[t]{2}{*}{2001} & Potamophase & $27.65(2.33)$ & $44.83(0.86)$ & $6.72(0.10)$ & $6.66(0.74)$ \\
\hline & & Limnophase & $21.10(0.01)$ & $40.20(0.01)$ & $6.26(0.01)$ & $8.78(0.01)$ \\
\hline & \multirow[t]{2}{*}{2002} & Potamophase & $26.89(0.72)$ & $38.23(4.48)$ & $7.74(0.73)$ & $6.53(0.83)$ \\
\hline & & Limnophase & 23.57 (3.91) & $43.72(9.33)$ & $6.91(0.27)$ & $7.25(0.39)$ \\
\hline & \multirow[t]{2}{*}{2003} & Potamophase & $27.70(0.01)$ & $49.27(0.32)$ & $6.64(0.11)$ & $7.15(0.37)$ \\
\hline & & Limnophase & $27.20(1.04)$ & $31.20(6.78)$ & $6.52(0.70)$ & 7.09 (1.23) \\
\hline & \multirow[t]{2}{*}{2004} & Potamophase & $23.75(5.31)$ & $42.42(3.73)$ & $6.84(0.85)$ & $6.85(0.69)$ \\
\hline & & Limnophase & $24.66(4.09)$ & $45.13(3.46)$ & $6.51(0.73)$ & $6.59(0.72)$ \\
\hline & \multirow[t]{2}{*}{2005} & Potamophase & $24.75(4.22)$ & 43.88 (3.09) & $7.16(0.14)$ & $7.24(0.77)$ \\
\hline & & Limnophase & $23.82(4.56)$ & $47.72(3.38)$ & $7.11(0.03)$ & $7.44(0.94)$ \\
\hline & \multirow[t]{2}{*}{2006} & Potamophase & $26.42(4.24)$ & 44.32 (1.17) & $6.73(0.49)$ & $6.76(1.15)$ \\
\hline & & Limnophase & 25.65 (3.77) & $45.22(2.22)$ & $7.11(0.50)$ & $6.97(1.03)$ \\
\hline & \multirow[t]{2}{*}{2007} & Potamophase & $25.43(4.67)$ & 45.75 (2.79) & $6.86(0.43)$ & $5.54(3.03)$ \\
\hline & & Limnophase & $26.27(1.58)$ & $44.87(3.14)$ & $7.26(0.42)$ & $7.00(0.73)$ \\
\hline
\end{tabular}


site. Data on the hydrometric levels were provided by the ANA (Agência Nacional de Águas).

Sediment samples were dried in an oven at $80{ }^{\circ} \mathrm{C}$. The granulometric texture was determined according to the Wentworth's scale (1922), using the wet method. Organic matter content in the sediment was obtained by calcination of the samples in a muffle at $560{ }^{\circ} \mathrm{C}$ for approximately four hours.

Biological material was washed through a set of sieves (2.0, 1.0, and $0.2 \mathrm{~mm}$ mesh sizes). The organisms found in the 2.0 and $1.0 \mathrm{~mm}$ mesh sieves were immediately fixed in $70 \%$ alcohol. The material retained in the $0.2 \mathrm{~mm}$ mesh sieve was placed in polyethylene jars containing $70 \%$ alcohol. The material was observed under a stereoscopic microscope at Nupélia/UEM Zoobenthos Laboratory.

Chironomidae larvae were identified down to the lowest taxonomic level possible using the identification keys of Epler (1992) and Trivinho-Strixino and Strixino (1995).

\subsection{Data analyses}

\subsubsection{Abiotic variables}

Principal Component Analysis (PCA) was used to reduce the dimensionality of the environmental variables and to rank rivers and study months in relation to the following types of organic matter: pebbles, granules, very coarse sand, coarse sand, medium sand, fine sand, very fine sand, and mud. Because of the low variability between environments and months, data on water temperature, dissolved oxygen concentration, $\mathrm{pH}$ and conductivity were not included in the analysis. To linearize the relationships and improve the results of PCA, data were processed using an arc-sine transformation. In this analysis, the first two axes were maintained for interpretation, according to the Kaiser-Guttman criterion.

A two-way ANOVA using the factors rivers and months was used to verify significant differences $(\alpha=0.05)$ in PCA scores. For this analysis we used the PC-ORD software program (version 4.0), and the Statistica software (version 7.0).

\subsubsection{Biotic variables}

Accumulation curves based on richness were used to compare the rivers and measure the efficiency of sampling through the estimators ACE, Jackniffe 1 and Bootstrap. The EstimateS (version 5.01) software was used.

To characterize the Chironomidae community in the studied rivers and months, Kownacki's dominance index (1971) was calculated, where: Dominant $=10<\mathrm{d}<100$; Subdominant $=1<\mathrm{d}<9.99$; and Adominant $=$ $0.01<\mathrm{d}<0.99$. Only the dominant taxa of each river and each month were listed.

The similarity of the Chironomidae community of rivers and years was measured using a cluster analysis by UPGMA method, using the Euclidian Distance. The cophenetic correlation coefficient (r) was generated us- ing a Mantel's Test. The program NTSYS (version 1.8) was used for this analysis.

To compare the diversity of rivers and months, the Shannon-Wienner ( $H^{\prime}$ ) index (Shannon and Weaver 1963) was used and the density of each sample was calculated by dividing the number of individuals collected from each sample by the sampled area.

A two-way ANOVA was used to verify significant differences $(\alpha=0.05)$ of density and diversity between rivers and between months. A Spearman's rank $(\mathrm{p}<0.05)$ was used with the purpose of analyzing the influence of the hydrometric level on the diversity and density of Chironomidae. The index of Beta Diversity (Whittaker, 1982) was applied to quantify the turnover of morphospecies between months.

\section{Results}

\subsection{Abiotic variables}

Summer floods of the Paraná and Ivinhema Rivers were almost simultaneous, except for 2002. The highest floods occurred in 2005 and 2007, and the lowest values were recorded in the second semester of 2001. Variations in 2000, 2001 and 2004 were quite irregular in comparison to the other years (Figure 2).

Granulometric data were summarized in a PCA, where principal components 1 and 2, with eigenvalues 2.34 and 1.74, explained 26.00 and $19.37 \%$ of the total variance in the data, respectively. Axis 1 separated the first four years from the others, mainly for Paraná River, because of the high mean percentages of sand and fine sand in the first years. The differences between the Paraná and Ivinhema rivers are evident in axis 2, mainly because of the high percentage of coarse particles in

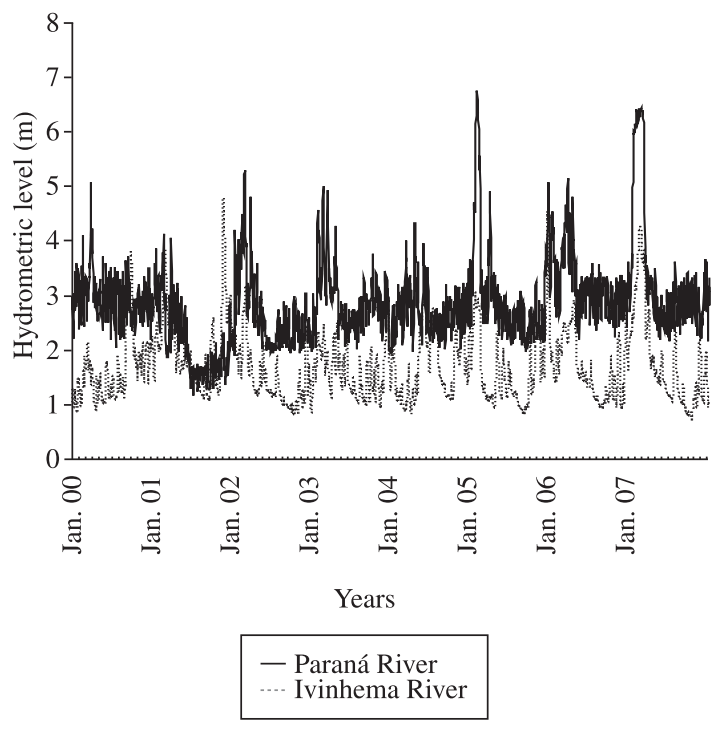

Figure 2. Hydrometric level of the Paraná and Ivinhema Rivers from January 2000 to December 2007. 
Paraná River and the fine particles and organic matter in the Ivinhema River (Figure 3). We found only significant $(\mathrm{p}<0.05)$ spatial differences and no significant temporal differences (Figure 4).

\subsection{Biotic variables}

The rarefaction curves indicated that the richness observed coincided with two of the three estimators in both rivers. Few new taxa occurred after September 2006 in the Ivinhema River and after November 2006 in the Paraná River. The application of estimators showed clearly that the samples were sufficient for proper assess- ment of diversity, providing support for accurate comparisons between the rivers (Figure 5).

We identified 5,761 Chironomidae larvae of 100 morphospecies (78 in the Paraná River and 62 in the Ivinhema River), distributed among 44 genera and three subfamilies (Tanypodinae, Chironominae and Orthocladiinae) (Appendix 1). Chironominae was the most abundant subfamily, corresponding to $71 \%$ of all individuals observed.

The Kownacki index showed that Polypedilum (Tripodura) sp.1 was the most dominant morphospe-

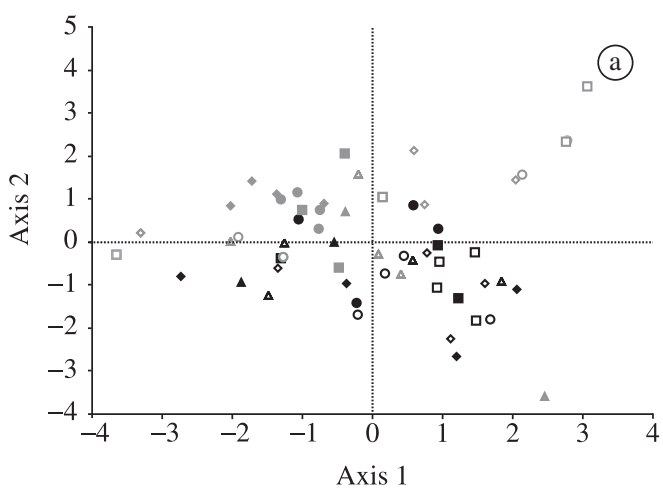

$$
\begin{aligned}
& \text { - PR00 ○ PR04 - IV00 ○ IV04 } \\
& \text { - PR01 a PR05 - IV01 IV05 } \\
& \text { - PR02 • PR06 * IV02 • IV06 } \\
& \text { ^ PR03 } \triangle \text { PR07 } \triangle \text { IV03 } \triangle \text { IV07 }
\end{aligned}
$$

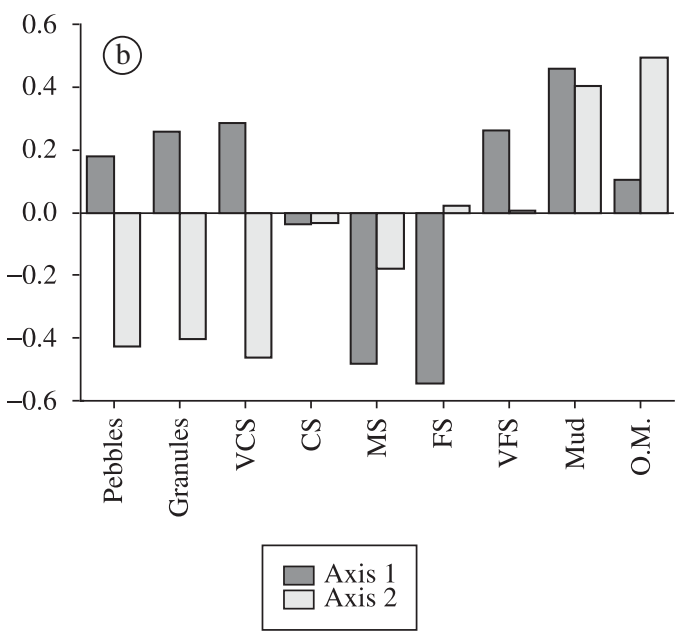

Figure 3. a) Ordination diagram of the first two axes of the PCA analysis. b) Eigenvectors of PCA variables. PR00 = Paraná River (2000); PR01 = Paraná River (2001); PR02 = Paraná River (2002); PR03 = Paraná River (2003); PR04 = Paraná River (2004); PR05 = Paraná River (2005); PR06 = Paraná River (2006); PR07 = Paraná River (2007), IV00 = Ivinhema River (2000); IV01 = Ivinhema River (2001); IV02 = Ivinhema River (2002); IV03 = Ivinhema River (2003); IV04 = Ivinhema River (2004); IV05 = Ivinhema River (2005); IV06 = Ivinhema River (2006); IV07 = Ivinhema River (2007);VCS = very coarse sand; $\mathrm{CS}=$ coarse sand; $\mathrm{MS}=$ medium sand; FS = fine sand; VFS = very fine sand; and OM = organic matter.
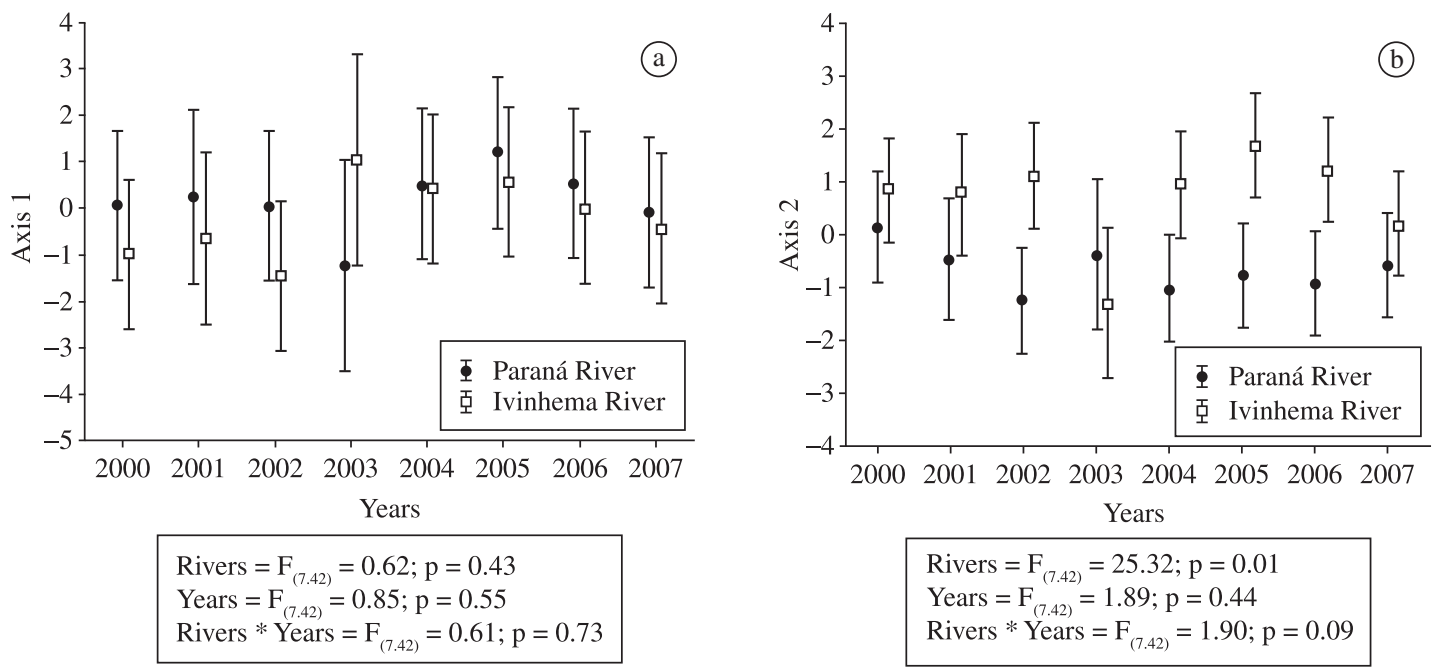

Figure 4. Mean \pm SE of the two-way ANOVA with a) axis 1 and b) 2 of PCA for the Paraná and Ivinhema Rivers. 
Table 2. Dominace values of Kownacki's index and dominants taxa of the rivers Paraná and Ivinhema in every months of sample. Feb00 = February 2000; May00 = May 2000; Aug00 = August 2000; Nov00 = November 2000; Feb01 = February 2001; May01 = May 2001; Aug01 = August 2001; Feb02 = February 2002; May02 = May 2002; Aug02 = August 2002; Nov02 = November 2002; Mar03 = March 2003; Sep03 = September 2003; Mar04 = March 2004; Jun04 = June 2004; Sep04 = September 2004; Dec04 = December 2004; Mar05 = March 2005; Jun05 = June 2005; Sep05 = September 2005; Dec05 = December 2005; Mar06 = March 2006; Jun06 = June 2006; Sep06 = September 2006; Nov06 = November 2006; Mar07 = March 2007; Jun07 = June 2007; Sep07 $=$ September 2007; Dec07 $=$ December 07. P. $($ Polypedilum $)$ sp.2 = Polypedilum (Polypedilum) sp.2; P. (Tripodura) sp.1 = Polypedilum (Tripodura) sp.1; A. (Karelia) sp.1 = Ablabesmyia (Karelia) sp.1

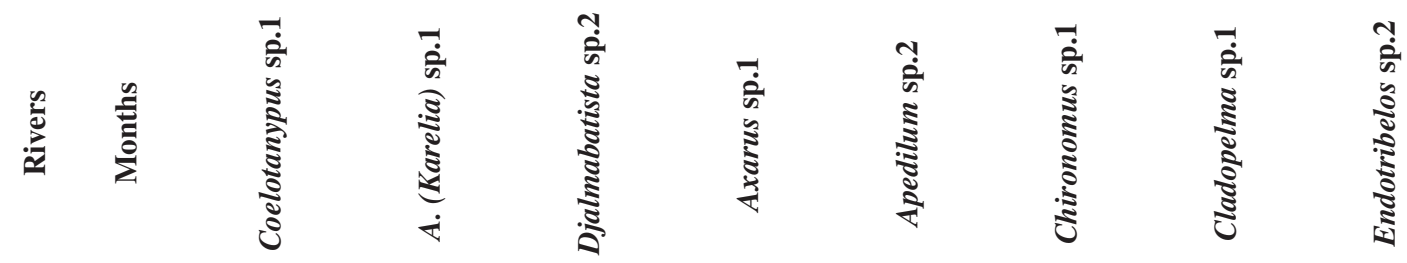

\begin{tabular}{|c|c|c|c|c|c|c|c|c|}
\hline Feb00 & - & - & - & - & - & - & - & - \\
\hline May00 & - & - & - & - & - & - & - & - \\
\hline Aug00 & - & - & - & - & - & - & - & - \\
\hline Nov00 & - & - & - & - & - & - & - & - \\
\hline Feb01 & - & - & - & - & - & - & - & - \\
\hline May01 & - & - & - & - & - & - & - & - \\
\hline Aug01 & - & - & - & - & - & - & - & - \\
\hline Feb02 & - & - & - & 35.90 & - & - & - & - \\
\hline Mai02 & - & - & - & - & - & - & - & - \\
\hline Aug02 & - & - & - & - & - & - & - & - \\
\hline Nov02 & - & - & - & - & - & - & - & - \\
\hline Mar03 & - & - & - & 21.21 & - & - & - & - \\
\hline Sep03 & - & - & - & - & - & - & - & - \\
\hline Mar04 & 14.77 & - & - & - & - & - & - & - \\
\hline Jun04 & - & - & - & - & - & - & - & - \\
\hline Sep04 & - & - & - & - & - & - & - & - \\
\hline Dec04 & 14.10 & - & - & - & - & - & - & - \\
\hline Mar05 & 10.00 & 20.00 & - & - & - & - & - & - \\
\hline Jun05 & - & - & - & - & - & - & - & - \\
\hline Sep05 & - & - & - & - & - & - & - & - \\
\hline Dec05 & - & - & 20.37 & - & - & - & - & - \\
\hline Mar06 & 14.06 & - & - & - & - & - & - & - \\
\hline Jun06 & - & - & - & - & - & - & - & - \\
\hline Sep06 & - & - & - & - & - & - & - & - \\
\hline Nov06 & - & 11.59 & - & - & - & - & - & - \\
\hline Mar07 & - & - & - & - & - & - & - & - \\
\hline Jun07 & - & - & - & - & - & - & - & - \\
\hline Sep07 & - & - & - & - & - & - & - & - \\
\hline Dec07 & - & - & - & - & - & - & - & - \\
\hline
\end{tabular}



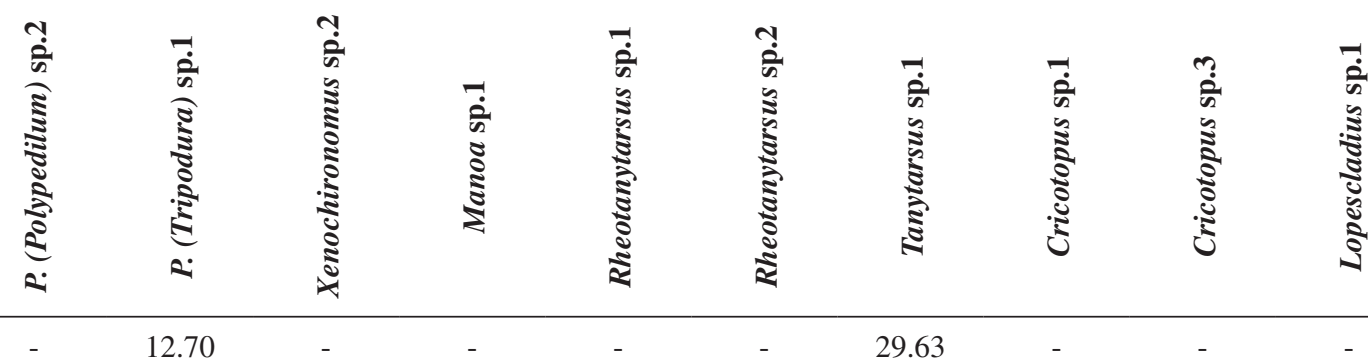

12.70

29.63

$15.20 \quad 28.27$

68.25

44.31

15.69

16.67

25.00

29.07

44.64

18.06

26.85

75.60

32.31

22.78

26.35

48.69

38.21

34.41

29.06

$19.18 \quad 11.64$

20.56

11.96

18.48

54.62

48.28

13.64 
Table 2. Continued...

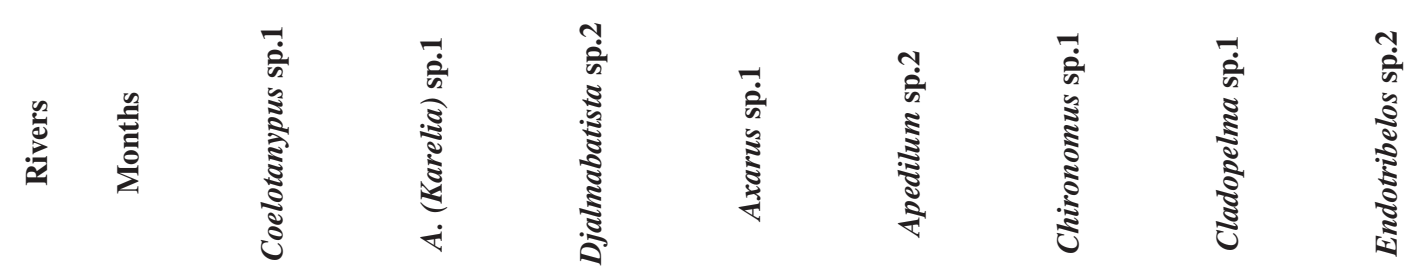

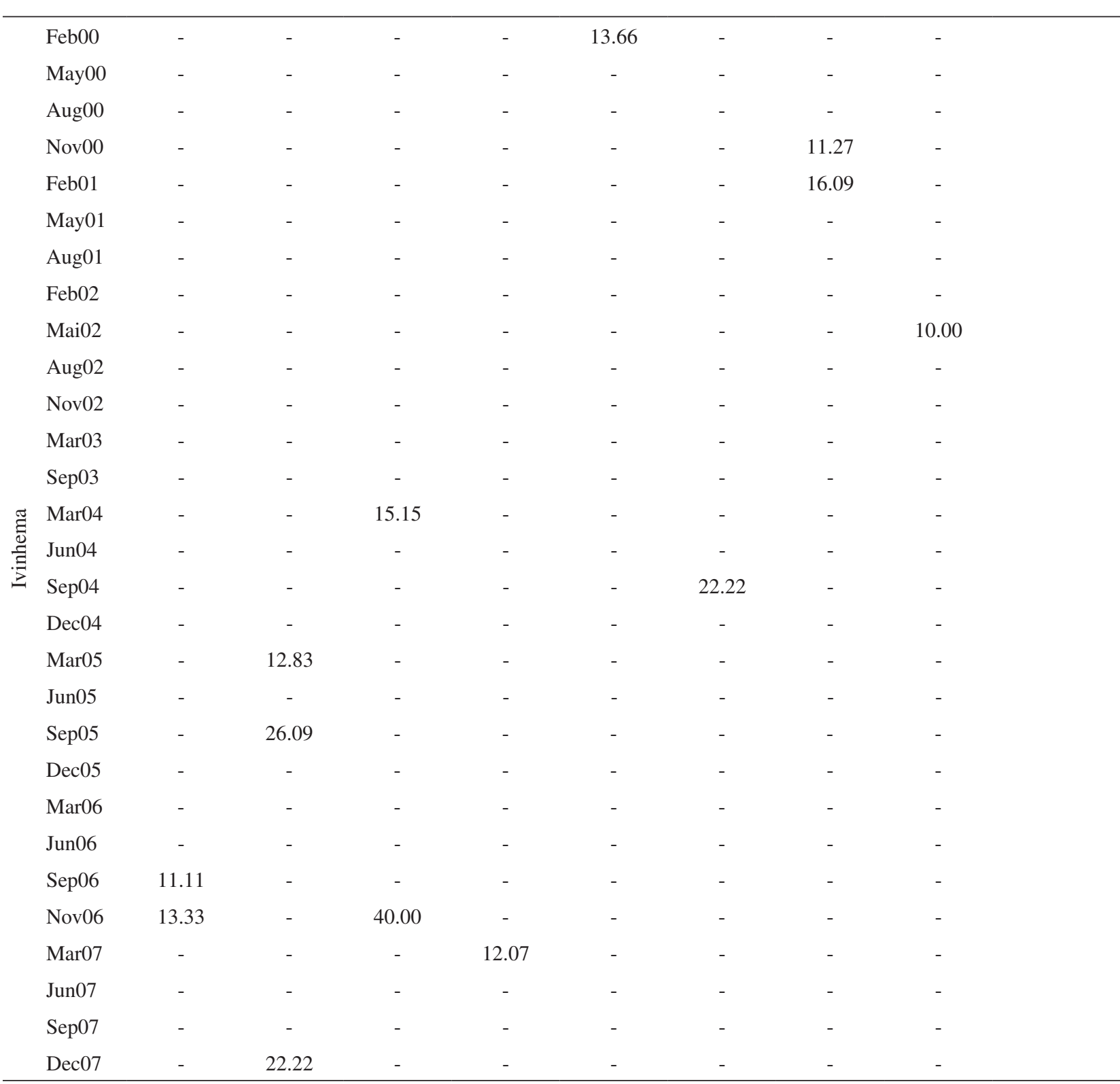



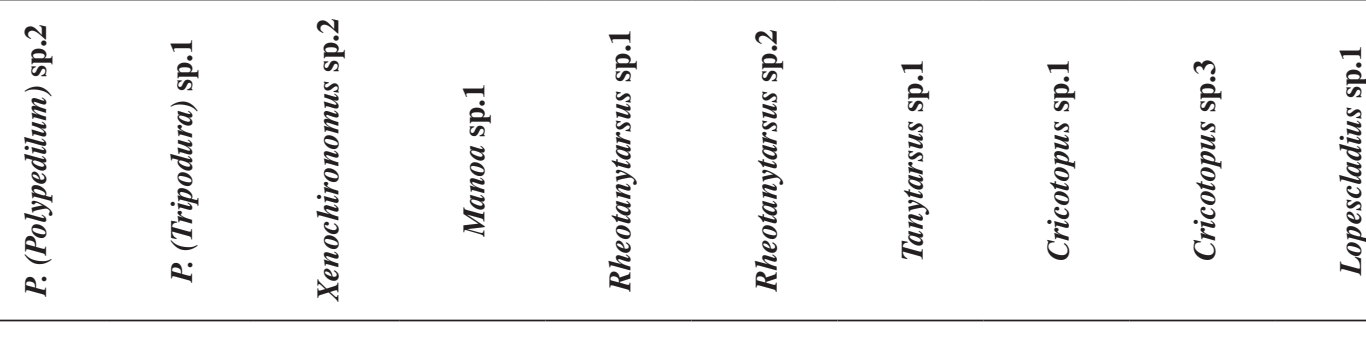

27.27

50.00

17.39 

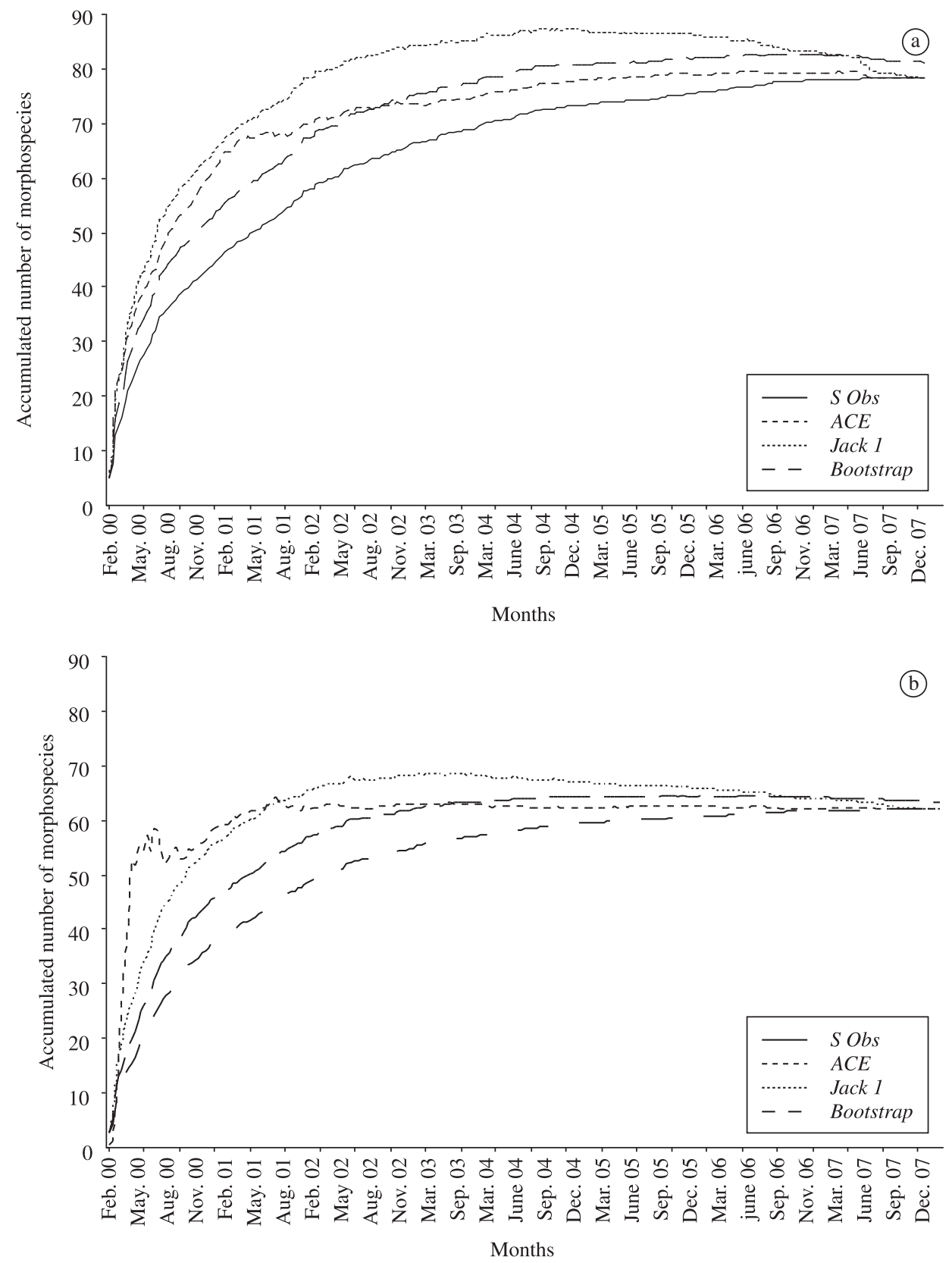

Figure 5. Richness observed (S Obs) and richness estimators ACE, Jack 1, and e Bootstrap for the a) Paraná and b) Ivinhema Rivers.

cies in the Paraná River, while in the Ivinhema River there was a large amount of variation in the dominant taxa and low values of dominance. We also noted that in the years 2000 and 2001, the dominant groups in each river were quite different. In the Paraná River the following species dominated: Polypedilum (Tripodura) sp.1, Polypedilum (Polypedilum) sp.2, Xenochironomus sp. 2, Tanytarsus sp. 1, Lopescladius sp. 1 and Manoa sp. 1. In the Ivinhema River the following species were dominant: Apedilum sp.2,
Polypedilum (Polypedilum) sp.2 and Cladopelma sp.1. However, after 2002, the main dominant taxa of the Paraná River (Polypedilum (Tripodura) sp. 1, Lopescladius sp. 1 and Tanytarsus sp. 1) also became dominant in the Ivinhema River. In addition, some new taxa have become dominant in both rivers: Coelotanypus sp. 1, Ablabesmyia (Karelia) sp. 1, Djalmabatista sp. 2 and Axarus sp. 1. (Table 2).

Based on the Euclidian Distance Analysis (UPGMA), we saw major differences in the composition and den- 
sity of Chironomidae of the Paraná River in the years 2000 and 2001. The Chironomidae community of the Ivinhema River was more similar throughout the study (Figure 6).

In the years 2000 and 2001, diversity patterns were similar for both rivers (Figure 7a). After this period, the values were more divergent because in the first samplings of 2003, 2005 and 2007, the diversity values of the Ivinhema River were much higher than those for the Paraná River. These differences were also indicated in the two-way ANOVA (Figure 7a). We verified that the density of larvae in the Paraná River increased between August and December in most years (all except for 2005). However, significant differences were observed only between the rivers (Figure $7 b$ ).

When we correlated the diversity and the density with the hydrometric levels (Spearman's rank; $p<0.05$ ), we observed a positive correlation between the diversity of the Ivinhema River and the hydrometric levels $(\mathrm{r}=0.34)$ and a negative correlation between the density of organisms in the Paraná River and the hydrometric levels $(\mathrm{r}=-0.38)$.

The index used to measure the Beta Diversity showed that in 2000 there were few changes in the composition of the community over the months studied. This pattern was not found in any of the following years. The total difference in the composition of morphospecies (1.0) was observed in February 2001 and in June and September of 2004. The greatest similarities were found after the periods of above average floods (Figure 8).

\section{Discussion}

The combined action of hydrological events in the Paraná and Ivinhema Rivers is primarily responsible for the geomorphological and ecological processes occurring across the floodplain (Rocha 2002). In the years 2000 and 2001 these events were severely affected by the second filling stage of the Porto Primavera Dam and aggravated by low precipitation from 1999 to 2001 (SouzaFilho et al., 2004)

The clustering observed between 2004 and 2007 in axis 1 of the PCA was influenced by the decrease in the percentages of medium and fine sand in the Paraná River, which is probably due to the geomorphological changes caused by the closing of the Porto Primavera Dam (Souza-Filho et al., 2004). The separation of the scores of the Paraná and Ivinhema Rivers, observed only in the second axis of the PCA, and the low percentage

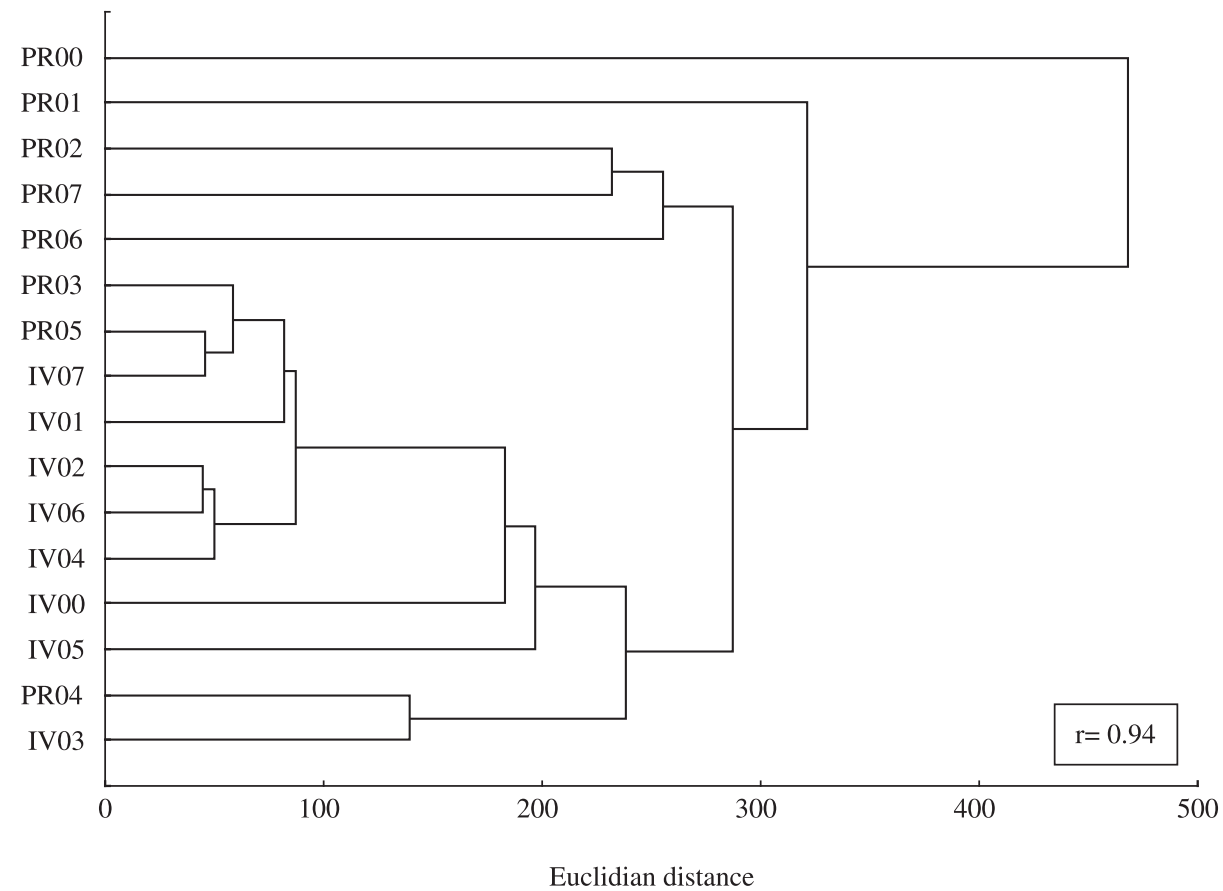

Figure 6. Cluster analyses (UPGMA) of the Chironomidae community of the rivers Paraná and based on Euclidean distance. $\mathrm{r}=$ cophenetic correlation (Mantel's test); PR00 = Paraná River (2000); PR01 = Paraná River (2001); PR02 = Paraná River (2002); PR03 = Paraná River (2003); PR04 = Paraná River (2004); PR05 = Paraná River (2005); PR06 = Paraná River (2006); PR07 = Paraná River (2007), IV00 = Ivinhema River (2000); IV01 = Ivinhema River (2001); IV 02 = Ivinhema River (2002); IV03 = Ivinhema River (2003); IV04 = Ivinhema River (2004); IV05 = Ivinhema River (2005); IV06 = Ivinhema River (2006); and IV07 = Ivinhema River (2007) 

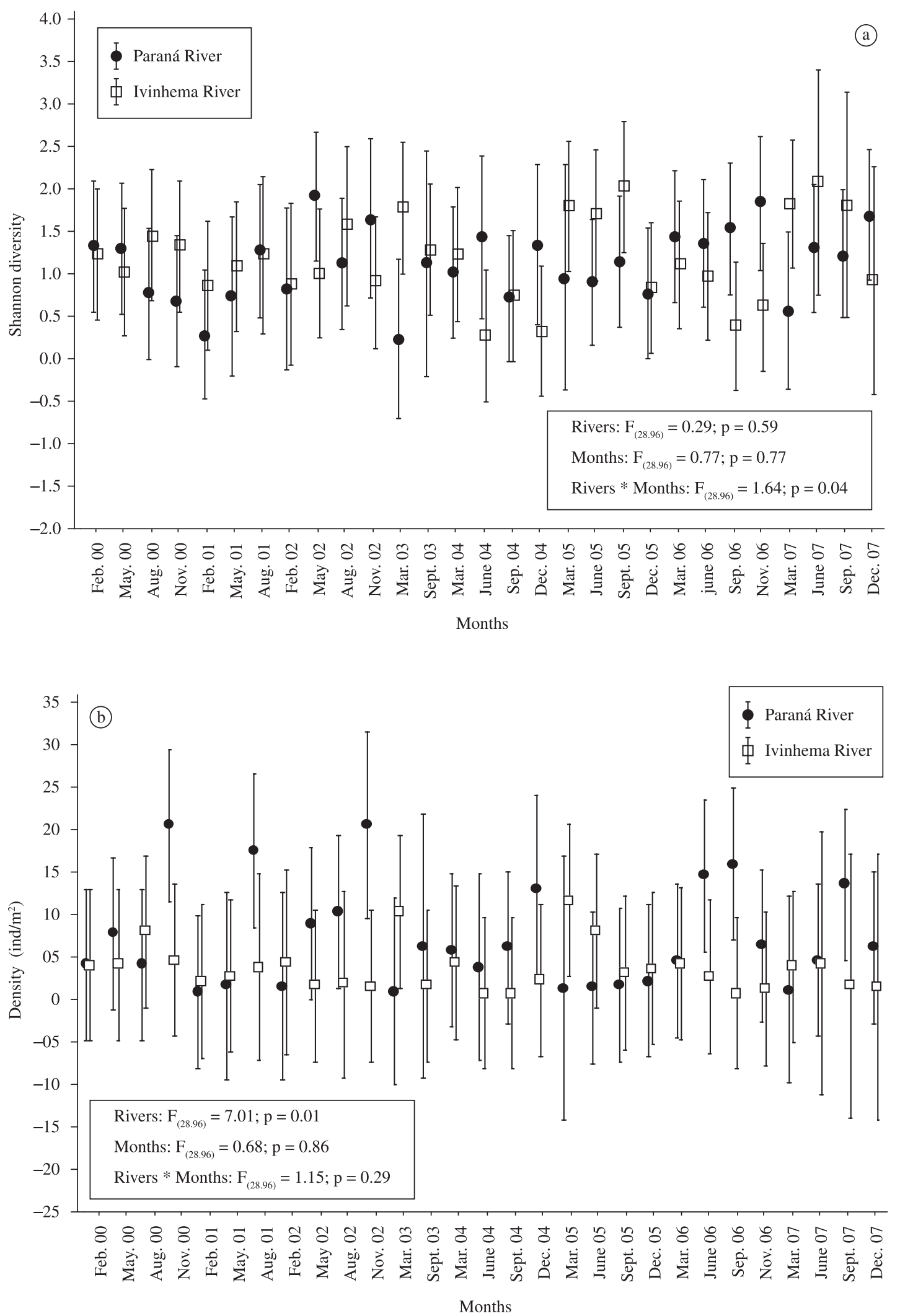

Figure 7. Mean \pm SD of a) Shannon-Wiener diversity and b) medium density of the Paraná and Ivinhema Rivers in every months of sampling. 


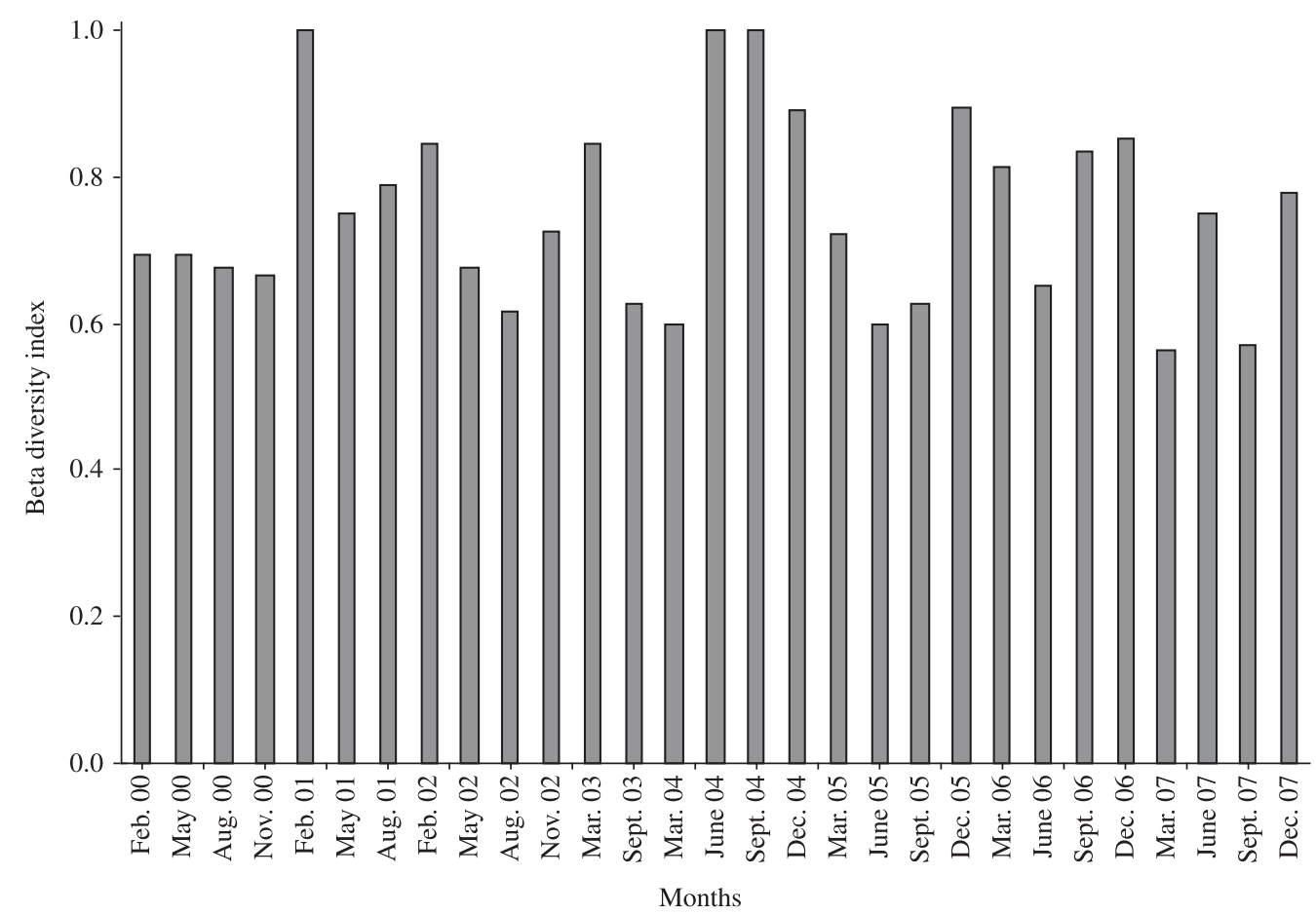

Figure 8. Beta Diversity index for every month of sampling.

of variation explained indicate that the differences in granulometric texture between these two rivers are not influential. However, the highest percentage of fine sediment in the Ivinhema River was a result of the high load of sediment carried by this river.

The high richness of Chironomidae taxa observed in the Paraná and Ivinhema Rivers in comparison with the world average for rivers of the same size ( 44 species according to Ferrington (2008)), emphasizes the importance of these environments for the maintenance of diversity. Higuti (2004) highlights that the richness of the lotic environments of the Upper Paraná River floodplain is greater than that found in the lentic environments since it encompasses a large part of the Chironomidae diversity of this ecosystem.

The patterns of dominance of the Ivinhema and Paraná Rivers became more similar after the year 2001. In some cases, the regulation of flow facilitates the dominance of some morphospecies (Munn and Brusven, 1991), which was probably the reason that the following species became dominant (Kownacki index) in the Paraná River and then in the Ivinhema River immediately after the second filling stage of the Porto Primavera reservoir: Polypedilum (Tripodura) sp.1, Lopescladius sp.1, Tanytarsus sp.1, Coelotanypus sp.1, Ablabesmyia (Karelia) sp.1, Djalmabatista sp.2 and Axarus sp.1.

The highest dominance values in the Paraná River are probably consequence of the reduction of the heterogeneity of the channel caused by the dams, since now most of the shapes of the riverbed have disappeared or are lim- ited in size (Souza-Filho et al., 2004). On the other hand, in the Ivinhema River we observed low values of dominance, which may be indicative of an environment with a greater abundance of available resources and a lower influence of competitors and predators (Ricklefs, 2003). Polypedilum was the dominant genus in both environments. This can be explained by the fact that this group is cosmopolitan, opportunistic and relatively resistant to adverse conditions (Panis et al., 1996).

We saw that the years 2000 and 2001 differed from the others, not only regarding the dominance, but also the in their composition and density (indicated in the Euclidian distance analysis). According to Rocha (2002), these years correspond to a period of strong changes in the flow of the Paraná River caused by the construction of the Porto Primavera Dam. An intense drought in late 2001 was probably also an influential factor. The new composition of morphospecies and the greater similarity of the following years are indicative of the recovery and adaptation of the community. The Chironomidae family is extraordinarily rich in species and has a high ecological plasticity, which gives makes this group successful in colonizing several types of environments (Cranston, 1995).

Through the Shannon-Wienner diversity index and the Spearman Rank, we confirmed that there is a connection between the events in the Paraná and Ivinhema Rivers after an above-average flood such as those in 2005 and 2007. We saw higher values of diversity in the Ivinhema River, while a decrease in density was ob- 
served in the Paraná River. These decreases in density in the Paraná River are likely related to increases in flow that can have deleterious effects on the benthic biota, and could even eliminate much of this community due to the "Shear Stress" (Layzer et al., 1989; Bunn and Arthington, 2002). However, in the Ivinhema River, the major floods seem to act as an incentive to the community, which responds by increasing the diversity of organisms.

Regardless of annual variations, there was an increase in the density of larvae in the Paraná River each spring. Rosin (2007) reports that this period is an important time of reproduction for these insects, and that they can even be multivoltinuous. In addition, in periods of low water, there is a reconstruction of habitat, favoring the permanence of the benthic community.

The values of Beta Diversity and the hydrometric levels were negatively correlated. This means that in the years that the flooding reached over $5.5 \mathrm{~m}$, the composition of the community was more similar (lower values of Beta Diversity). The caused an increase in the connectivity between environments and a drift of organisms during periods of high waters. Similar results were found by Amoros and Bornette (2002) for the zoobenthic community.

It was evident that the major structural changes in the Chironomidae community occurred immediately after the end of the second filling stage of the Porto Primavera Dam and that in subsequent years the community has adapted to the new conditions, entering into new cycles and patterns of dominance.

Despite the sequence of damming, the Chironomidae community continues to respond to fluctuations in the hydrometric levels, maintaining periods of diversity and reproduction even when there are differences in composition. We can also consider that, despite being free of dams, the Ivinhema River is also influenced by the events occurring in the Paraná River because the diversity increases in the Ivinhema River after flood periods.

Acknowledgements - We acknowledge for financial support of the LTER (Long Term Ecological Research) project by the CNPq (Conselho Nacional de Pesquisa em Ciência e Tecnologia), and thank the physics and chemistry laboratory of Nupelia for providing water quality data. We also thank the ANA (Agência Nacional das Águas) and Itaipu Binacional for the hydrometric level data.

\section{References}

AGOSTINHO, AA., THOMAZ, SM. and GOMES, LC., 2004. Threats for biodiversity in the floodplain of the upper Paraná River: effects of hydrological regulation by dams. Ecohydrology \& Hydrobiology, vol. 4 , no. 3, p. 255-268

AGOSTINHO, AA., PELICICE, FM. and GOMES, LC., 2008. Dams and the fish fauna of the Neotropical region: impacts and management related to diversity and fisheries. Revista Brasileira de Biologia = Brazilian Journal of Biology, vol. 68, no. (4 suppl), p. 1119-1132.
AMOROS, C. and BORNETTE, G., 2002. Connectivity and biocomplexity in waterbodies of riverine floodplains. Freshwater Biology, vol. 47, no. 4, p. 761-776.

BUNN, SE. and ARTHINGTON, AH., 2002. Basic principles and ecological consequences of altered flow regimes for aquatic biodiversity. Environment \& Management, vol. 30, no. 4, p. $492-507$

CRANSTON, PS., 1995. Introduction. In ARMITAGE, P., CRANSTON, PS. and PINDER, LCV.(Eds.). The Chironomidae, bioloy and ecology of non-biting midges. London: Chapman and Hall. p. 1-5.

EPLER, JH., 1995. Identification manual for the larval Chironomidae of Florida. Tallahassee: Florida Department of Environmental Regulation. 319p.

FESL, C., 2002 Biodiversity and resource af larval chironomids in relation to environmental factors in a large river. Freshwater Biology, vol. 47, no. 6, p. 1065-1087.

FERRINGTON, LC., 2008. Global diversity of non-biting midges (Chironomidae; Insecta-Diptera) in freshwater. Hydrobiologia, vol. 595, no. 1, p. 447-455.

HAYAKAWA, EH., 2007. Análise da variabilidade espacial e temporal dos sedimentos suspensos do Alto rio Paraná via imagens orbitais: região de porto São José - PR. Maringá: Universidade Estadual de Maringá - UEM. 84p. Dissertação de Mestrado.

HIGUTI, J. and TAKEDA, AM., 2002. Spatial and temporal variation in of Chironomid larval (Diptera) in two lagoons and two tributaries of the Upper Paraná River floodplain, Brazil. Revista Brasileira de Biologia $=$ Brazilian Journal of Biology, vol. 62 , no. 4, p. 807-818

HIGUTI, J., 2004. Composition, abundance and hábitats of benthic chironomid larvae. In THOMAZ, SM., AGOSTINHO, AA. and HAHN, NS. (Eds.). The Upper Paraná River and its floodplain: physical aspects, ecology and conservation. Leiden: Backhuys Publishers. p. 209-222.

KOWNACKI, A., 1971. Taxocens of Chironomidae in streams of the Polish High Tatra Mts. (Str.). Acta Hydrobiologica, vol. 13 , no. 4 , p. $439-464$.

LAYZER, JB., NEHUS, TJ., PENNINGTON, W., GORE, JA. and NESTLER, JM., 1989. Seasonal variation in the composition of drift below a peaking hydroelectric project. Regulated Rivers: Research \& Management, vol. 3, no. 1, p. 29-34.

LUNDQVIST, J., 1998. Avert looming hydrocide. Ambio, vol. 27 , no. 6 , p. $428-433$.

MUNN, MD. and BRUSVEN, MA., 1991. Benthic invertebrate communities in nonregulated and regulated waters of the Clearwater River, Idaho, USA. Regulated Rivers: Research \& Management, vol. 6, no. 1, p. 1-11.

NAIMAN, RJ., MAGNUSON, JJ., McKNIGHT, DM. and STANFORD, JA., 1995. The freshwater imperative: a research agenda. Washington DC: Island Press. 165p.

PANIS, LI., GODDEERIS, B., VERHEYEN, R., 1996. On the relationship between vertical microdistribution and adaptations to oxygen strees in litoral Chironomidae (Diptera). Hydrobiologia, vol. 318, no. 1-3, p. 61-67.

PIEDRAS, SRN., BAGER, A., MORAES, PRR., LORAINE, AI., FERREIRA, OGLF. and HEEMANN, C., 2006. 
Macroinvertebrados bentônicos como indicadores de qualidade de água na Barragem Santa Bárbara, Pelotas, RS, Brasil. Ciência Rural, vol. 36, no. 2, p. 494-500.

PINDER, LCV., 1995. The habitats of Chironomidae larvae. In ARMITAGE, P., CRANSTON, PS. and PINDER, LCV. (Eds.). The Chironomidae, bioloy and ecology of non-biting midges. London: Chapman and Hall. p. 107-117.

RICKLEFS, RE., 2003. A economia da natureza. 5 ed. Rio de Janeiro: Guanabara Koogan. 503p.

ROCHA, PC., 2002. Dinâmica dos canais no Sistema RioPlanície Fluvial do Alto Rio Paraná, nas proximidades de Porto Rico - PR. Maringá: Universidade Estadual de Maringá - UEM. 172p. Tese de Doutorado.

ROCHA, PC., SANTOS, ML. and SOUZA-FILHO, EE., 2001. Alterações no regime hidrológico do alto rio Paraná como resposta ao controle de descargas efetuado por grandes barramentos a montante. In Anais do VIII Encuentro de Geógrafos de América Latina, Março 4-10. Santiago: [s.n.], 2001. p. 28-39. 1 CD-ROM.

ROCHA, PC., SOUZA-FILHO, EE. and FERNANDEZ, OVQ., 1998. Aspectos do controle de descargas efetuado por barramentos no alto rio Paraná. Boletim Paranaense de Geociências, vol. 46, p. 117-122.

ROCHA, RRA. and THOMAZ, SM., 2004. Variação temporal de fatores limnológicos em ambientes da planície de inundação do alto rio Paraná (PR/MS-Brasil). Acta Scientiarum Biological Sciences, vol. 26, no. 3, p. 261-271.

ROSIN, GC. and TAKEDA, AM., 2007. Larvas de Chironomidae (Diptera) da planície de inundação do alto rio Paraná: distribuição e composição em diferentes ambientes e fases hídricas. Acta Scientiarum Biological Sciences, vol. 29, no. 1, p. $57-63$.

ROSIN, GC., 2007. Larvas de Chironomidae em substratos artificiais: comparações e padrões de colonização em três rios da planície de inundação do alto rio Paraná, Brasil. Maringá: Universidade Estadual de Maringá - UEM. 26p. Dissertação de Mestrado.

SHANNON, CE. and WEAVER, W., 1963. The mathematical theory of communication. Illinois: University Press Urbana. $125 \mathrm{p}$.

SILVA, SA., 2007. Mecanismos de transmissão de fluxos de água e sedimentos em dois grandes rios aluviais impactados pela atividade humana: o Araguaia e o Paraná. Maringá: Universidade Estadual de Maringá - UEM. 136p. Tese de Doutorado.

SOUZA FILHO, EE. and STEVAUX, JC., 2004. Geology and geomorphology of the Baia-Curutuba-Ivinheima complex. In
THOMAZ, SM., AGOSTINHO, AA. and HAHN, NS. (Eds.). The Upper Paraná River and its floodplain: physical aspects, ecology and conservation. Leiden: Backhuys Publishers. p. 01-29

SOUZA-FILHO, EE., ROCHA, PC., COMUNELlO, E. and STEVAUX, JC., 2004. Effects of the Porto Primavera Dam on physical environment of the downstream floodplain. In THOMAZ, SM., AGOSTINHO, AA. and HAHN, NS. (Eds.). The Upper Paraná River and its floodplain: physical aspects, ecology and conservation. Leiden: Backhuys Publishers. p. 55-74.

SPARKS, RE., 1995. Need for ecosystem management of large Rivers and floodplains. BioScience, vol. 45, no. 3, p. 168-182.

SPECZIÁR, A. and BIRÓ, P., 1998. Spatial distribution and short-term changes of benthic macrofauna in Lake Balaton (Hungary). Hydrobiologia, vol. 389, no. 1-3, p. 203-216.

STEVAUX, JC., SOUZA-FILHO, EE. and JABUR, IC., 1997 A história quaternária do rio Paraná em seu alto curso. In VAZZOLER, AEAM., AGOSTINHO, AA. and HAHN, NS. (Eds.). A Planície de inundação do Alto Rio Paraná: aspectos físicos, biológicos e socio-econômicos. Maringá: Eduem. p. 47-72.

TAKEDA, AM., KOBAYASHI, JT., RESENDE, DLMC., FUJITA, DS., AVELINO, GS., FUJITA, RH., PAVAN, CB. and BUTAKKA, CMM., 2004. Influence of decreased water level on the Chironomidae community of the Upper Paraná River alluvial plain. In AGOSTINHO, AA., RODRIGUES, L., GOMES, LC., THOMAZ, SM. and MIRANDA, LE. (Eds.). Structure and functioning of the Paraná River and its floodplain LTER-site 6 (Peld-sitio 6). Maringá: Eduem. p. 101-106.

TAKEDA, AM., SHIMIZU, GM. and HIGUTI, J., 1997. Variações espaço-temporais da comunidade zoobêntica. In VAZZOLER, AEAM., AGOSTINHO, AA. and HAHN, NS. (Eds.). A Planície de inundação do Alto Rio Paraná: aspectos físicos, biológicos e socio-econômicos. Maringá: Eduem. p. $157-177$.

TRIVINHO-STRIXINO, S. and STRIXINO, G., 1995. Larvas de Chironomidae (Diptera) do Estado de São Paulo. Guia de identificação e diagnose dos gêneros. São Carlos: PPG-ERN, UFSCar. 229p.

WARD, JV. and STANFORD, JA., 1995. Ecological connectivity in alluvial river ecosystems and its disruption by flow regulation. Regulated Rivers: Research \& Management, vol. 11 , no. 1 , p. 105-119.

WENTWORTH, CK., 1922. A scale of grade and class trems for clastic sediments. Journal of Geology, vol. 30, p. 377-392.

WHITTAKER, RH., 1982. Evolution and measurement of species diversity. Taxon, vol. 21, no. 5, p. 213-251. 
Appendix 1. Morphospecies list and relative frequency of Chironomidae taxa (\%) in the Paraná and Ivinhema Rivers. PR 00-01 = Paraná River (2000-2001); PR 02-03 = Paraná River (2002-2003); PR 04-05 = Paraná River (2004-2005); PR 06-07 = Ivinhema River (2006-2007); IV 00-01 = Ivinhema River (2000-2001); IV 02-03 = Ivinhema River (2002-2003); IV 04-05 = Ivinhema River (2004-2005); and IV 06-07 = Ivinhema River (2006-2007).

\begin{tabular}{|c|c|c|c|c|c|c|c|c|}
\hline & $\begin{array}{c}\text { PR } \\
\text { 00-01 }\end{array}$ & $\begin{array}{c}\text { PR } \\
02-03\end{array}$ & $\begin{array}{c}\text { PR } \\
\text { 04-05 }\end{array}$ & $\begin{array}{c}\text { PR } \\
\text { 06-07 }\end{array}$ & $\begin{array}{c}\text { IV } \\
00-01\end{array}$ & $\begin{array}{c}\text { IV } \\
02-03\end{array}$ & $\begin{array}{c}\text { IV } \\
04-05\end{array}$ & $\begin{array}{c}\text { IV } \\
06-07\end{array}$ \\
\hline \multicolumn{9}{|l|}{ TANYPODINAE } \\
\hline Tanypodinae spp. & 0.11 & 0.00 & 0.00 & 0.26 & 0.00 & 0.00 & 0.00 & 0.00 \\
\hline \multicolumn{9}{|l|}{ Coelotanypodini } \\
\hline Clinotanypus sp.1 & 0.00 & 0.00 & 0.12 & 0.00 & 0.00 & 0.00 & 0.00 & 0.00 \\
\hline Coelotanypus sp.1 & 0.11 & 0.17 & 14.59 & 1.74 & 3.02 & 4.20 & 2.30 & 3.24 \\
\hline \multicolumn{9}{|l|}{ Pentaneurini } \\
\hline Ablabesmyia (Karelia) sp.1 & 0.44 & 1.52 & 4.20 & 5.37 & 0.23 & 0.35 & 10.54 & 5.09 \\
\hline Larsia sp. 1 & 0.00 & 0.00 & 0.00 & 0.05 & 0.23 & 0.00 & 0.00 & 0.00 \\
\hline \multicolumn{9}{|l|}{ Procladiini } \\
\hline Djalmabatista pulcher (Johannsen, 1908) & 0.11 & 0.17 & 0.12 & 0.15 & 2.09 & 0.35 & 0.19 & 0.00 \\
\hline Djalmabatista sp.2 & 0.55 & 0.51 & 4.82 & 1.74 & 1.62 & 5.94 & 4.21 & 8.80 \\
\hline Djalmabatista sp.3 & 0.00 & 0.00 & 0.00 & 0.00 & 0.00 & 3.50 & 1.92 & 0.00 \\
\hline Djalmabatista sp.4 & 0.00 & 0.00 & 0.00 & 0.00 & 0.00 & 0.00 & 0.77 & 0.00 \\
\hline Procladius sp.1 & 0.00 & 0.00 & 0.00 & 0.00 & 0.00 & 0.70 & 0.77 & 0.46 \\
\hline \multicolumn{9}{|l|}{ Tanypodini } \\
\hline Tanypus sp.1 & 0.00 & 0.00 & 0.25 & 0.00 & 0.00 & 0.00 & 0.00 & 0.00 \\
\hline \multicolumn{9}{|l|}{ CHIRONOMINAE } \\
\hline \multicolumn{9}{|l|}{ Chironomini } \\
\hline Apedilum sp.2 & 0.00 & 0.00 & 0.00 & 0.00 & 6.26 & 0.00 & 0.00 & 0.00 \\
\hline Axarus sp.1 & 0.55 & 3.86 & 0.00 & 0.00 & 6.26 & 1.05 & 4.98 & 4.63 \\
\hline Beardius sp.1 & 0.00 & 0.17 & 0.00 & 0.00 & 0.00 & 0.00 & 0.00 & 0.00 \\
\hline Beardius sp.2 & 0.00 & 0.00 & 0.00 & 0.00 & 0.23 & 0.00 & 0.38 & 0.00 \\
\hline Chironomus spp. & 0.55 & 0.34 & 0.00 & 0.00 & 0.70 & 0.70 & 0.38 & 0.46 \\
\hline $\begin{array}{l}\text { Chironomus antonioi } \\
\text { (Correia and Trivinho-Strixino, 2007) }\end{array}$ & 0.00 & 0.00 & 0.00 & 0.05 & 0.00 & 0.00 & 0.00 & 0.00 \\
\hline $\begin{array}{l}\text { Chironomus fittkaui } \\
\text { (Correia and Trivinho-Strixino, 2007) }\end{array}$ & 0.11 & 0.00 & 0.00 & 0.05 & 0.00 & 0.00 & 0.00 & 0.00 \\
\hline Chironomus gr. salinarius sp.1 & 0.00 & 0.00 & 0.00 & 0.26 & 0.00 & 0.00 & 0.00 & 0.00 \\
\hline Chironomus gr. decorus sp.1 & 0.00 & 0.51 & 0.12 & 0.00 & 0.00 & 0.00 & 0.00 & 0.00 \\
\hline Chironomus sp.1 & 0.00 & 0.00 & 0.00 & 0.00 & 0.70 & 1.05 & 0.96 & 0.93 \\
\hline Chironomus sp.2 & 0.00 & 0.00 & 0.00 & 0.00 & 0.70 & 0.35 & 0.00 & 0.00 \\
\hline Cladopelma sp.1 & 0.00 & 0.00 & 2.22 & 1.79 & 11.14 & 0.35 & 0.19 & 0.00 \\
\hline Cladopelma sp.2 & 0.00 & 0.00 & 0.00 & 0.00 & 2.32 & 1.05 & 0.96 & 0.00 \\
\hline Complexo Harnischia spp. & 0.11 & 0.00 & 0.00 & 0.00 & 0.23 & 0.00 & 0.00 & 0.46 \\
\hline Cryptochironomus sp.1 & 1.66 & 0.34 & 1.85 & 0.20 & 2.32 & 0.00 & 0.19 & 1.39 \\
\hline Cryptochironomus sp. 2 & 0.00 & 5.10 & 1.48 & 4.19 & 0.00 & 0.35 & 1.53 & 4.63 \\
\hline Demicryptochironomus sp.1 & 1.88 & 0.00 & 0.62 & 0.00 & 0.00 & 0.00 & 0.00 & 0.00 \\
\hline Demicryptochironomus sp.2 & 0.22 & 0.00 & 0.00 & 0.00 & 0.00 & 0.00 & 0.00 & 0.00 \\
\hline Dicrotendipes spp. & 0.22 & 0.00 & 0.00 & 0.00 & 0.00 & 0.00 & 0.00 & 0.00 \\
\hline Dicrotendipes sp.1 & 0.00 & 0.34 & 0.00 & 0.00 & 0.00 & 0.00 & 0.00 & 0.00 \\
\hline Dicrotendipes sp. 3 & 0.11 & 0.00 & 0.00 & 0.10 & 0.00 & 0.00 & 0.00 & 0.00 \\
\hline Endotribelos sp.1 & 0.00 & 1.18 & 0.25 & 0.10 & 0.00 & 0.00 & 2.49 & 0.00 \\
\hline Endotribelos sp.2 & 0.44 & 0.60 & 0.37 & 0.15 & 0.93 & 2.80 & 0.38 & 1.39 \\
\hline $\begin{array}{l}\text { Fissimentum dessicatum } \\
\text { (Cranston and Nolte, 1996) }\end{array}$ & 0.00 & 1.11 & 0.12 & 0.00 & 2.09 & 0.00 & 0.19 & 0.00 \\
\hline
\end{tabular}


Appendix 1. Continued...

\begin{tabular}{|c|c|c|c|c|c|c|c|c|}
\hline & $\begin{array}{c}\text { PR } \\
\text { 00-01 }\end{array}$ & $\begin{array}{c}\text { PR } \\
\text { 02-03 }\end{array}$ & $\begin{array}{c}\text { PR } \\
04-05\end{array}$ & $\begin{array}{c}\text { PR } \\
\text { 06-07 }\end{array}$ & $\begin{array}{c}\text { IV } \\
00-01 \\
\end{array}$ & $\begin{array}{c}\text { IV } \\
02-03\end{array}$ & $\begin{array}{c}\text { IV } \\
04-05 \\
\end{array}$ & $\begin{array}{c}\text { IV } \\
06-07\end{array}$ \\
\hline Fissimentum sp.2 & 0.22 & 0.51 & 0.12 & 0.20 & 0.70 & 0.00 & 0.19 & 0.00 \\
\hline Fissimentum sp.3 & 0.78 & 0.17 & 0.00 & 0.15 & 0.00 & 0.00 & 0.00 & 0.00 \\
\hline $\begin{array}{l}\text { Goeldichironomus luridus } \\
\text { (Trivinho-Strixino and Strixino, 2005) }\end{array}$ & 0.00 & 0.17 & 0.00 & 0.00 & 0.00 & 0.00 & 0.00 & 0.00 \\
\hline Goeldichironomus xiborena (Reiss, 1974) & 0.00 & 0.00 & 0.00 & 0.00 & 0.00 & 1.05 & 0.00 & 0.00 \\
\hline Goeldichironomus gr. pictus sp.1 & 0.00 & 0.00 & 0.00 & 0.00 & 2.09 & 1.05 & 0.19 & 0.00 \\
\hline Pelomus sp.1 & 0.00 & 0.00 & 0.00 & 0.00 & 0.23 & 0.35 & 0.00 & 0.00 \\
\hline Lauterborniella sp.1 & 0.00 & 0.00 & 0.00 & 0.00 & 0.00 & 0.00 & 0.19 & 0.00 \\
\hline Nilothauma sp.1 & 0.22 & 0.17 & 0.00 & 0.10 & 0.00 & 0.00 & 0.00 & 0.00 \\
\hline Nilothauma sp.2 & 0.00 & 0.00 & 0.00 & 0.00 & 0.00 & 0.00 & 0.38 & 0.00 \\
\hline Parachironomus spp. & 0.11 & 0.00 & 0.00 & 0.00 & 0.00 & 0.00 & 0.00 & 0.00 \\
\hline Parachironomus sp.1 & 0.00 & 0.68 & 1.48 & 0.10 & 0.23 & 1.05 & 1.92 & 3.70 \\
\hline Parachironomus sp. 2 & 0.00 & 0.00 & 0.12 & 0.00 & 0.00 & 0.00 & 0.96 & 0.00 \\
\hline Parachironomus sp.4 & 0.00 & 0.00 & 0.12 & 0.20 & 0.00 & 0.00 & 0.00 & 0.00 \\
\hline Paralauterborniella sp.1 & 0.00 & 0.00 & 0.12 & 2.40 & 0.00 & 0.70 & 0.96 & 0.00 \\
\hline Phaenopsectra sp.1 & 0.11 & 0.17 & 0.00 & 0.61 & 0.00 & 0.00 & 0.00 & 0.00 \\
\hline Phaenopsectra sp.2 & 0.44 & 0.00 & 0.00 & 0.77 & 0.00 & 0.00 & 0.00 & 0.00 \\
\hline Polypedilum (Asheum) sp.1 & 0.00 & 1.02 & 0.00 & 0.05 & 0.23 & 0.00 & 1.15 & 0.00 \\
\hline Polypedilum (Polypedilum) sp.1 & 0.11 & 0.00 & 0.00 & 0.36 & 6.03 & 1.05 & 1.34 & 0.00 \\
\hline Polypedilum (Polypedilum) sp.2 & 4.32 & 5.60 & 0.62 & 4.85 & 28.31 & 0.70 & 1.72 & 0.46 \\
\hline Polypedilum (Polypedilum) sp.3 & 0.00 & 0.00 & 0.00 & 0.00 & 0.00 & 1.75 & 0.77 & 0.93 \\
\hline Polypedilum (Tripodura) sp.1 & 38.80 & 27.49 & 24.35 & 31.32 & 3.48 & 8.39 & 20.31 & 6.48 \\
\hline Polypedilum (Tripodura) sp.2 & 0.00 & 3.06 & 0.00 & 2.96 & 0.00 & 0.00 & 0.00 & 0.00 \\
\hline Robackia sp.1 & 0.33 & 0.51 & 0.00 & 0.15 & 9.51 & 0.35 & 0.38 & 0.46 \\
\hline Robackia sp.2 & 0.00 & 0.00 & 0.00 & 0.00 & 1.39 & 0.00 & 0.19 & 0.00 \\
\hline Saetheria tylus (Townes, 1945) & 0.67 & 0.00 & 0.25 & 0.10 & 0.00 & 0.00 & 0.00 & 0.00 \\
\hline Saetheria sp.1 & 0.00 & 0.34 & 0.74 & 0.15 & 0.00 & 1.75 & 0.96 & 2.31 \\
\hline Saetheria sp.2 & 0.00 & 0.17 & 0.87 & 0.00 & 0.00 & 0.00 & 0.00 & 0.00 \\
\hline Stenochironomus sp.1 & 0.00 & 0.00 & 0.00 & 0.15 & 0.00 & 0.00 & 1.72 & 1.39 \\
\hline Xenochironomus sp.2 & 0.44 & 0.00 & 0.00 & 0.00 & 0.00 & 0.00 & 0.00 & 0.00 \\
\hline Zavreliella sp.2 & 0.00 & 0.00 & 0.00 & 0.00 & 0.00 & 0.35 & 0.38 & 1.85 \\
\hline \multicolumn{9}{|l|}{ Pseudochironomini } \\
\hline Pseudochironomini spp. & 0.11 & 0.00 & 0.00 & 0.15 & 0.00 & 0.00 & 0.00 & 0.00 \\
\hline Aedokritus sp.1 & 0.00 & 0.17 & 0.12 & 0.05 & 0.23 & 1.75 & 0.77 & 0.00 \\
\hline Manoa sp.1 & 9.31 & 1.69 & 1.98 & 3.53 & 0.00 & 0.00 & 0.00 & 0.00 \\
\hline Pseudochironomus sp.1 & 0.22 & 0.17 & 0.25 & 0.26 & 0.00 & 0.00 & 0.00 & 0.00 \\
\hline Pseudochironomus sp.2 & 0.00 & 0.00 & 0.00 & 0.51 & 0.00 & 0.00 & 0.00 & 0.00 \\
\hline Pseudochironomus sp.3 & 0.00 & 0.00 & 0.00 & 0.10 & 0.00 & 0.00 & 0.00 & 0.00 \\
\hline \multicolumn{9}{|l|}{ Tanytarsini } \\
\hline Tanytarsini spp. & 0.22 & 0.00 & 0.00 & 0.41 & 0.00 & 0.00 & 0.00 & 0.00 \\
\hline Caladomyia spp. & 0.00 & 0.00 & 0.00 & 0.05 & 2.78 & 0.00 & 0.57 & 0.00 \\
\hline Caladomyia castelnaiu (Säwedal, 1981) & 0.00 & 0.00 & 0.00 & 0.00 & 0.23 & 0.70 & 0.19 & 0.93 \\
\hline Caladomyia ortoni (Säwedal, 1981) & 0.44 & 0.00 & 0.12 & 0.26 & 0.00 & 0.00 & 0.00 & 0.46 \\
\hline Caladomyia riotarumensis (Reiff, 2000) & 0.11 & 0.00 & 0.00 & 0.00 & 0.00 & 0.00 & 0.00 & 0.00 \\
\hline Caladomyia sp.1 & 0.00 & 0.17 & 0.12 & 0.56 & 0.00 & 0.00 & 0.00 & 0.00 \\
\hline Caladomyia sp.2 & 0.00 & 0.00 & 0.00 & 0.05 & 0.00 & 0.00 & 0.57 & 0.00 \\
\hline Caladomyia sp. 3 & 0.00 & 0.00 & 0.00 & 0.00 & 1.62 & 3.85 & 3.45 & 0.00 \\
\hline
\end{tabular}


Appendix 1. Continued...

\begin{tabular}{|c|c|c|c|c|c|c|c|c|}
\hline & $\begin{array}{c}\text { PR } \\
\text { 00-01 }\end{array}$ & $\begin{array}{c}\text { PR } \\
\text { 02-03 }\end{array}$ & $\begin{array}{c}\text { PR } \\
\text { 04-05 }\end{array}$ & $\begin{array}{c}\text { PR } \\
\text { 06-07 }\end{array}$ & $\begin{array}{c}\text { IV } \\
00-01\end{array}$ & $\begin{array}{c}\text { IV } \\
02-03\end{array}$ & $\begin{array}{c}\text { IV } \\
04-05\end{array}$ & $\begin{array}{c}\text { IV } \\
06-07\end{array}$ \\
\hline Rheotanytarsus sp.1 & 0.00 & 0.00 & 0.00 & 0.20 & 0.00 & 0.00 & 8.62 & 0.00 \\
\hline Rheotanytarsus sp. 2 & 0.00 & 0.00 & 0.00 & 0.00 & 0.00 & 0.00 & 0.00 & 10.19 \\
\hline Stempellina sp.1 & 0.00 & 0.00 & 0.00 & 0.61 & 0.00 & 0.00 & 0.00 & 0.00 \\
\hline Stempellinela sp.1 & 0.00 & 0.00 & 0.12 & 0.00 & 0.00 & 0.00 & 0.00 & 0.00 \\
\hline Tanytarsus spp. & 0.00 & 0.00 & 0.00 & 0.00 & 0.00 & 0.00 & 0.19 & 0.00 \\
\hline $\begin{array}{l}\text { Tanytarsus rhabdometis } \\
\text { (Trivinho-Strixino and Strixino, 1991) }\end{array}$ & 0.00 & 0.00 & 0.00 & 0.41 & 0.00 & 0.00 & 0.00 & 0.00 \\
\hline Tanytarsus sp.1 & 15.63 & 12.79 & 29.30 & 9.76 & 1.86 & 25.87 & 1.15 & 0.93 \\
\hline Tanytarsus sp.2 & 0.00 & 0.17 & 0.12 & 0.26 & 0.00 & 0.00 & 0.00 & 1.39 \\
\hline Tanytarsus sp.3 & 0.00 & 0.68 & 0.00 & 0.20 & 0.00 & 0.70 & 0.00 & 1.39 \\
\hline Tanytarsus sp.4 & 0.00 & 0.00 & 0.00 & 0.87 & 0.00 & 0.00 & 0.00 & 0.00 \\
\hline \multicolumn{9}{|l|}{ ORTHOCLADIINAE } \\
\hline Orthocladiinae spp. & 0.00 & 0.00 & 0.00 & 0.05 & 0.00 & 0.00 & 0.00 & 0.00 \\
\hline Corynoneura sp.1 & 0.00 & 0.00 & 0.12 & 0.00 & 0.00 & 0.35 & 0.38 & 0.00 \\
\hline Corynoneura sp.2 & 0.00 & 0.00 & 0.00 & 0.00 & 0.00 & 0.00 & 0.19 & 3.70 \\
\hline Cricotopus sp.1 & 3.66 & 1.18 & 2.10 & 10.32 & 0.00 & 0.35 & 0.19 & 0.00 \\
\hline Cricotopus sp.2 & 0.11 & 0.00 & 0.00 & 0.66 & 0.00 & 0.00 & 0.00 & 0.00 \\
\hline Cricotopus sp. 3 & 1.55 & 3.38 & 1.48 & 7.66 & 0.00 & 1.40 & 0.77 & 0.93 \\
\hline Lopescladius sp.1 & 14.86 & 23.63 & 4.20 & 1.89 & 0.00 & 22.73 & 15.90 & 29.63 \\
\hline Nanocladius sp.1 & 0.00 & 0.00 & 0.00 & 0.00 & 0.00 & 0.35 & 0.00 & 0.00 \\
\hline Onconeura sp.1 & 0.00 & 0.00 & 0.00 & 0.15 & 0.00 & 0.00 & 0.00 & 1.39 \\
\hline Thienemanniella sp.1 & 0.00 & 0.00 & 0.00 & 0.05 & 0.00 & 0.35 & 0.00 & 0.00 \\
\hline Thienemanniella sp.3 & 0.00 & 0.00 & 0.00 & 0.10 & 0.00 & 0.00 & 0.00 & 0.00 \\
\hline
\end{tabular}

